\title{
Tiotropium and the treatment of chronic obstructive pulmonary disease
}

\section{Le tiotropium et le traitement de la maladie pulmonaire obstructive chronique}

$\mathrm{I}^{\mathrm{n}}$ In the present issue of the Canadian Respiratory Journal, Chan et al (1) report the results of a large Canadian trial studying the long-acting anticholinergic tiotropium in patients with stable chronic obstructive pulmonary disease (COPD). Approximately 900 patients from a wide variety of practices were recruited and treated for approximately one year with tiotropium or placebo in double-blinded fashion. They were allowed access to other drugs with the exception of other inhaled anticholinergics and long-acting beta 2 -agonists. Specifically, inhaled corticosteroid use was permitted. The primary end point was 'trough' (predose) values of forced expiratory volume in $1 \mathrm{~s}\left(\mathrm{FEV}_{1}\right)$, but quality of life, exacerbations and hospitalizations, and use of rescue medication - short-acting beta-agonists - were also enumerated and analyzed. Outcomes were somewhat clouded by the fact that patients on placebo had a greater tendency to drop out or be given anticholinergics than those on tiotropium. Nevertheless, those on tiopropium had higher levels of trough $\mathrm{FEV}_{1}$ and better quality of life than those on placebo. There was no difference between groups in exacerbations or hospitalizations, and the authors showed that current smokers responded just as well as ex-smokers.

This is one of a considerable series of large double-blind therapeutic trials in COPD, largely supported by the pharmaceutical industry (2-8; this is not a complete list), and there are more to come. These trials have studied tiotropium, inhaled steroids, and combinations of inhaled steroids and long-acting bronchodilators. Many have been positive in that patients on the agent studied have done better than controls. What do we now know? I shall try to consider the common threads that emerge from a very large amount of data by looking at the usual outcomes of these studies.

First, there is little evidence that any or all of these agents change the course of the disease, as assessed by change in $\mathrm{FEV}_{1}$ over time. $\mathrm{FEV}_{1}$ is, indeed, increased by all the drugs studied, but in all cases, including the Chan study (1), measurements have compared patients who had study drug in their systems at the time of testing with those who did not. This is more or less the same as measuring $\mathrm{FEV}_{1}$ before and after two puffs of salbutamol and concluding that the drug changed the disease. The acid test for change in the course of the disease is measurements made after the experimental drug has been washed out, as in the Lung Health Study (9).

Use of 'rescue medications' is a less common end point for entirely justifiable reasons. Many studies that involve relatively long-acting medications, including steroids, should decrease the use of rescue medications for symptomatic benefit. It is
Dans le présent numéro du Journal canadien de pneumologie, Chan et coll. (1) présentent les résultats d'une vaste étude canadienne portant sur un anticholinergique à action prolongée, le tiotropium, chez les patients atteints d'une maladie pulmonaire obstructive chronique (MPOC). On a recruté environ 900 patients provenant de nombreux cabinets et on les a traités à double insu avec du tiotropium ou un placebo, pendant environ un an. Ces patients pouvaient prendre d'autres médicaments, à l'exception d'autres anticholinergiques en aérosol et des bêta agonistes à action prolongée. Les corticoïdes en aérosol étaient autorisés. Les valeurs « creuses » (avant la dose) du volume expiratoire maximal par seconde (VEMS) étaient le paramètre ultime primaire, mais la qualité de vie, les exacerbations et les hospitalisations, de même que le recours à des médicaments de rattrapage (les bêta-agonistes à action brève) étaient également pris en compte et analysés. Les résultats étaient quelque peu obscurcis par le fait que les patients sous placebo avaient plus tendance à abandonner ou à prendre des anticholinergiques que les patients qui prenaient du tiotropium. Néanmoins, les patients qui prenaient du tiotropium présentaient un taux plus élevé de VEMS creux et une meilleure qualité de vie que les patients sous placebo. On ne remarquait aucune différence entre les groupes pour ce qui est des exacerbations ou des hospitalisations, et les auteurs ont démontré que les fumeurs réagissaient aussi bien que les anciens fumeurs.

Ce n'est qu'une étude sur une série considérable de vastes essais thérapeutiques à double insu sur la MPOC, en grande partie soutenus par l'industrie pharmaceutique (2-8; liste partielle), et d'autres sont à venir. Ces essais ont porté sur le tiotropium, les stéroïdes en aérosol et les associations de stéroïdes en aérosol et de bronchodilatateurs à action prolongée. De nombreux essais ont donné des résultats positifs puisque les patients qui prenaient l'agent à l'étude obtenaient de meilleurs résultats que les sujets témoins. Que fait-on maintenant ? Je vais tenter d'examiner les points communs qui émergent d'énormes quantités de données en évaluant les résultats habituels de ces études.

D'abord, peu de données indiquent que la totalité ou une partie de ces agents changent pendant l'évolution de la maladie, d'après les modifications du VEMS au fil du temps. En effet, le VEMS augmente grâce à tous les médicaments à l'étude, mais dans tous les cas, y compris l'étude de Chan (1), les mesures comparaient des patients qui avaient le médicament à l'étude dans leur système à des patients qui n'en avaient pas. C'est à peu près la même chose que de mesurer le VEMS avant et après deux bouffées de salbutamol et de conclure que le médicament modifie la maladie. Des mesures effectuées après l'évacuation du médicament à l'étude, comme dans l'étude sur la santé pulmonaire (9), constitue l'épreuve décisive de changement pendant l'évolution de la maladie. 
hardly surprising that daily tiotroprium, a long-acting bronchodilator, decreases the need for short-acting agents. Indeed, the increase in salbutamol use in the Chan study amounted to only six puffs per week on average, a surprisingly small number in patients with serious disease. It is perhaps justifiable to ask precisely what trial participants were told in regard to the use of these agents.

Quality of life has usually been evaluated by the St George's Respiratory Questionnaire, a valuable tool in COPD assessment. Both long-acting beta-agonists and tiotropium increase quality of life. This is presumably because patients who have sustained bronchodilation have fewer symptoms than those who do not, and makes excellent sense. Whether the same effects could be achieved by assiduous use of short-acting agents has not, to my knowledge, been assessed, but it would seem likely that they could. Inhaled steroids also improve quality of life, and the mechanism of this effect is less clear. It may be because they too increase the $\mathrm{FEV}_{1}$ somewhat, but I think this is less certain. In any event, it is safe to say that both long-acting bronchodilators and inhaled steroids improve quality of life in COPD.

Exacerbations are a common end point of COPD trials. This makes sense, because these events drive costs associated with the disease and cause considerable morbidity. They also occur often enough to constitute an end point that can be achieved in a slightly smaller study than, say, change in $\mathrm{FEV}_{1}$. However, exacerbations are slippery in that they are hard to define and the significance of the individual event is not always clear. Current evaluation of exacerbations is essentially an enumeration of health care use, which may or may not relate to biological events. While Chan et al did not find that tiotropium reduced exacerbations, others have shown that this may be the case. It is also reasonably well established that inhaled steroids have a similar effect. The effects of long-acting beta-agonists on exacerbations are less clear. I believe that inhaled steroids have a place in COPD management and may be given in conjunction with a long-acting bronchodilator. It is not clear whether the exacerbations prevented by inhaled steroids would be prevented by, say, tiotropium, but it seems likely that this is the case, at least in part. Even with these drugs, patients have exacerbations, and the biology of these events is uncertain and probably variable.

A problem with many of these trials has been that patients not receiving the agent under study have had high dropout rates compared with those getting the investigative drug, even though the studies were double blind. These dropouts were often due to the patient being given the drug that they were forbidden by the rules of the study, and appears to indicate that all of these drugs had some effect on patient and physician satisfaction.

Finally, special mention should be made of another recent Canadian trial, which was atypically supported by a noncommercial interest: the Canadian Institutes of Health Research (8). It compared tiotropium with tiotropium plus a long-acting beta-agonist and with tiotropium plus a combination of inhaled steroid and long-acting beta-agonist. For fiscal reasons, it was underpowered in comparison with industrysponsored trials, including that of Chan et al (1). It found that the group receiving tiotropium and the combination drug had
Le recours à des médicaments de rattrapage est un point ultime moins courant, pour des raisons tout à fait justifiables. De nombreuses études qui portent sur des médicaments dont l'action est relativement prolongée, y compris les stérö̈des, devraient limiter le recours aux médicaments de rattrapage pour obtenir des bienfaits symptomatiques. Il est à peine surprenant que des doses quotidiennes de tiotropium, un bronchodilatateur à action prolongée, réduisent la nécessité de prendre des agents à action brève. En fait, l'augmentation de l'usage de salbutamol dans l'étude de Chan correspondait à une moyenne de seulement six bouffées par semaine, une quantité étonnamment limitée pour des patients atteints d'une maladie grave. Il est peut-être justifié de demander ce qu'on a dit aux patients au sujet de l'utilisation de ces agents.

Le questionnaire respiratoire de St George est généralement utilisé pour évaluer la qualité de vie, car c'est un outil précieux d'évaluation de la MPOC. Les bêta-agonistes à action prolongée et le tiotropium améliorent tous deux la qualité de vie. C'est probablement parce que les patients qui reçoivent une bronchodilatation soutenue présentent moins de symptômes que ceux qui n'en reçoivent pas, ce qui est très logique. Pour autant que je sache, on n'a pas évalué si on pouvait parvenir aux mêmes effets grâce à l'utilisation assidue d'agents à action brève, mais c'est un résultat qui semble probable. Les stéroïdes en aérosol améliorent également la qualité de vie, et le mécanisme de son effet est moins évident. Ce peut être parce qu'ils apportent une certaine amélioration du VEMS, mais je pense que c'est moins sûr. Quoi qu'il en soit, on peut affirmer sans se tromper que les bronchodilatateurs à action prolongée et les stéroïdes en aérosol améliorent tous deux la qualité de vie des patients atteints de MPOC.

Les exacerbations sont un paramètre ultime courant des essais sur la MPOC. C'est logique, parce que ces événements augmentent les coûts associés à la maladie et provoquent une morbidité considérable. De plus, ils se produisent assez souvent pour constituer un paramètre ultime réalisable dans une étude relativement plus petite que, disons, un changement au VEMS. Cependant, les exacerbations constituent un terrain glissant parce qu'elles sont difficiles à définir et qu'on ne peut pas toujours établir clairement la signification d'un seul événement. L'évaluation courante des exacerbations se résume à peu près au recours aux soins de santé, qui peut être relié ou non à des événements biologiques. Chan et coll. n'ont pas conclu que le tiotropium réduisait les exacerbations, mais d'autres ont démontré que ce peut être le cas. Il est également raisonnablement bien établi que les stéroïdes en aérosol donnent un effet similaire. Les effets des bêtaagonistes à action prolongée sur les exacerbations sont moins clairs. Je pense que les stéroïdes en aérosol ont leur place dans la prise en charge de la MPOC et qu'ils peuvent être administrés conjointement avec un bronchodilatateur à action prolongée. On ne sait pas si les exacerbations prévenues par les stéroïdes en aérosol seraient prévenues par le tiotropium, disons, mais il semble probable que ce soit le cas, du moins en partie. Même avec ces médicaments, les patients ont des exacerbations, et la biologie de ces événements est incertaine et probablement variable.

Bon nombre de ces essais comportent un problème : les patients qui ne prennent pas l'agent à l'étude présentent un taux d'abandon élevé par rapport à ceux qui le reçoivent, même si les études sont à double insu. Ces abandons sont souvent causés par le fait qu'on administre aux patients un médicament qu'ils n'ont pas le droit de prendre d'après les règles de l'étude, et ils semblent indiquer que tous ces médicaments avaient un effet sur la satisfaction du patient et du médecin. 
fewer hospitalizations and better quality of life than the other two, supporting my prosteroid bias.

Nick R Anthonisen MD

Editor-in-Chief, Canadian Respiratory Journal

\section{REFERENCES}

1. Chan CKN, Maltais F, Sigouin C, Haddon JM, Ford GT; on behalf of the SAFE Study Group. A randomized controlled trial to assess the efficacy of tiotropium in Canadian patients with chronic obstructive pulmonary disease. Can Respir J 2007;14(8):465-472.

2. Burge PS, Calverley PM, Jones PW, Spencer S, Anderson JA, Maslen TK. Randomised, double blind, placebo controlled study of fluticasone propionate in patients with moderate to severe chronic obstructive pulmonary disease: The ISOLDE trial. BMJ 2000;320:1297-303.

3. Calverley PM, Boonsawat W, Cseke Z, Zhong N, Peterson S, Olsson H. Maintenance therapy with budesonide and formoterol in chronic obstructive pulmonary disease. Eur Respir J 2003;22:912-9. (Erratum in 2004;24:1075).

4. Calverley P, Pauwels R, Vestbo J, et al. Combined salmeterol and fluticasone in the treatment of chronic obstructive pulmonary disease: A randomised controlled trial. Lancet 2003;361:449-56. (Erratum in 2003;361:1660).

5. Casaburi R, Mahler DA, Jones PW, et al. A long-term evaluation of once-daily inhaled tiotropium in chronic obstructive pulmonary disease. Eur Respir J 2002;19:217-24.

6. Niewoehner DE, Rice K, Cote C, et al. Prevention of exacerbations of chronic obstructive pulmonary disease with tiotropium, a once-daily inhaled anticholinergic bronchodilator: A randomized trial. Ann Intern Med 2005;143:317-26.

7. Calverley PM, Anderson JA, Celli B, et al; for the TORCH investigators. Salmeterol and fluticasone propionate and survival in chronic obstructive pulmonary disease. N Engl J Med 2007;356:775-89.

8. Aaron SD, Vandemheen KL, Fergusson D, et al. Tiotropium in combination with placebo, salmeterol, or fluticasone-salmeterol for treatment of chronic obstructive pulmonary disease: A randomized trial. Ann Intern Med 2007;146:545-55.

9. Anthonisen NR, Connett JE, Kiley JP, et al. Effects of smoking intervention and the use of an inhaled anticholinergic bronchodilator on the rate of decline of $\mathrm{FEV}_{1}$. The Lung Health Study. JAMA 1994:272:1497-505.
Enfin, un autre essai canadien récent mérite d'être souligné. De manière atypique, il n'était pas soutenu par un intérêt commercial : les Instituts de recherche en santé du Canada (8), Cet essai comparait le tiotropium à une association de stéroïdes en aérosol et d'un bêta-agoniste à action prolongée. Pour des raisons fiscales, il était en sous-effectif par rapport aux essais commandités par l'industrie, y compris l'essai de Chan et coll. (1). Cet essai a établi que le groupe qui recevait le tiotropium et la thérapie associative se faisait moins hospitaliser et profitait d'une meilleure qualité de vie que les deux autres groupes, ce qui étaye mon parti pris pour les stéroïdes.

Nick R. Anthonisen, M.D. Rédacteur en chef, Journal canadien de pneumologie

\section{RÉFÉRENCES}

1. Chan CKN, Maltais F, Sigouin C, Haddon JM, Ford GT; on behalf of the SAFE Study Group. A randomized controlled trial to assess the efficacy of tiotropium in Canadian patients with chronic obstructive pulmonary disease. Can Respir J 2007;14(8):465-472.

2. Burge PS, Calverley PM, Jones PW, Spencer S, Anderson JA, Maslen TK. Randomised, double blind, placebo controlled study of fluticasone propionate in patients with moderate to severe chronic obstructive pulmonary disease: The ISOLDE trial. BMJ 2000;320:1297-303.

3. Calverley PM, Boonsawat W, Cseke Z, Zhong N, Peterson S, Olsson H. Maintenance therapy with budesonide and formoterol in chronic obstructive pulmonary disease. Eur Respir J 2003;22:912-9. (Erratum in 2004;24:1075).

4. Calverley P, Pauwels R, Vestbo J et coll. Combined salmeterol and fluticasone in the treatment of chronic obstructive pulmonary disease: A randomised controlled trial. Lancet 2003;361:449-56. (Erratum in 2003;361:1660).

5. Casaburi R, Mahler DA, Jones PW et coll. A long-term evaluation of once-daily inhaled tiotropium in chronic obstructive pulmonary disease. Eur Respir J 2002;19:217-24.

6. Niewoehner DE, Rice K, Cote C et coll. Prevention of exacerbations of chronic obstructive pulmonary disease with tiotropium, a once-daily inhaled anticholinergic bronchodilator: A randomized trial. Ann Intern Med 2005;143:317-26.

7. Calverley PM, Anderson JA, Celli B et coll; for the TORCH investigators. Salmeterol and fluticasone propionate and survival in chronic obstructive pulmonary disease. N Engl J Med 2007;356:775-89.

8. Aaron SD, Vandemheen KL, Fergusson D et coll. Tiotropium in combination with placebo, salmeterol, or fluticasone-salmeterol for treatment of chronic obstructive pulmonary disease: A randomized trial. Ann Intern Med 2007;146:545-55.

9. Anthonisen NR, Connett JE, Kiley JP et coll. Effects of smoking intervention and the use of an inhaled anticholinergic bronchodilator on the rate of decline of $\mathrm{FEV}_{1}$. The Lung Health Study. JAMA 1994;272:1497-505. 


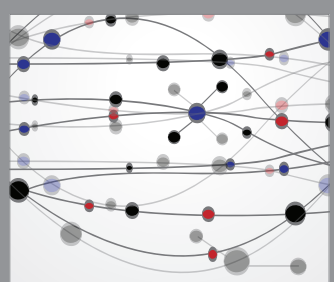

The Scientific World Journal
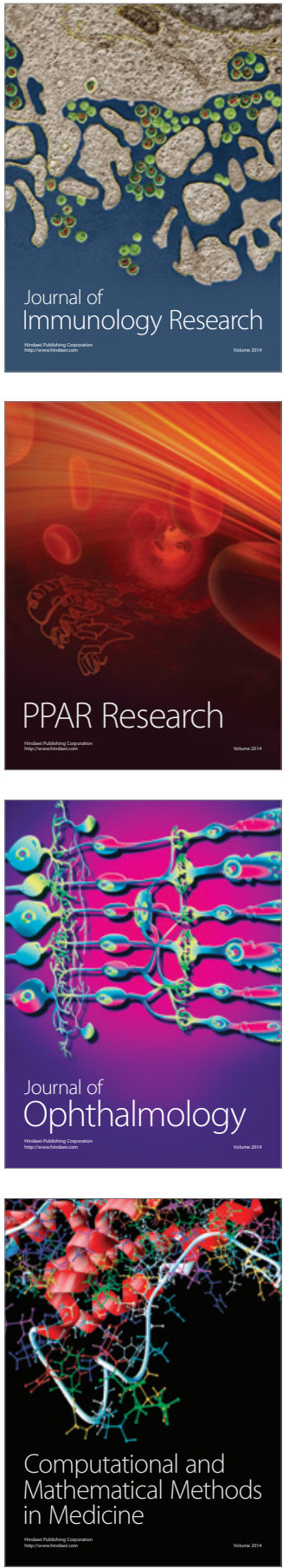

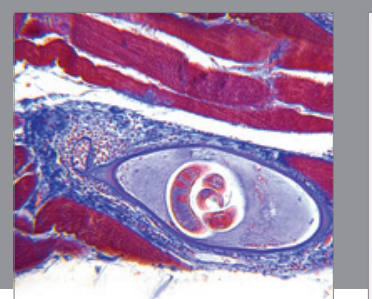

Gastroenterology Research and Practice

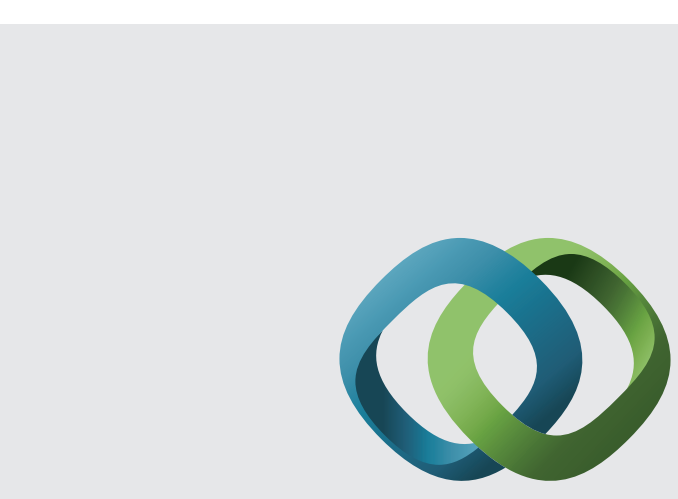

\section{Hindawi}

Submit your manuscripts at

http://www.hindawi.com
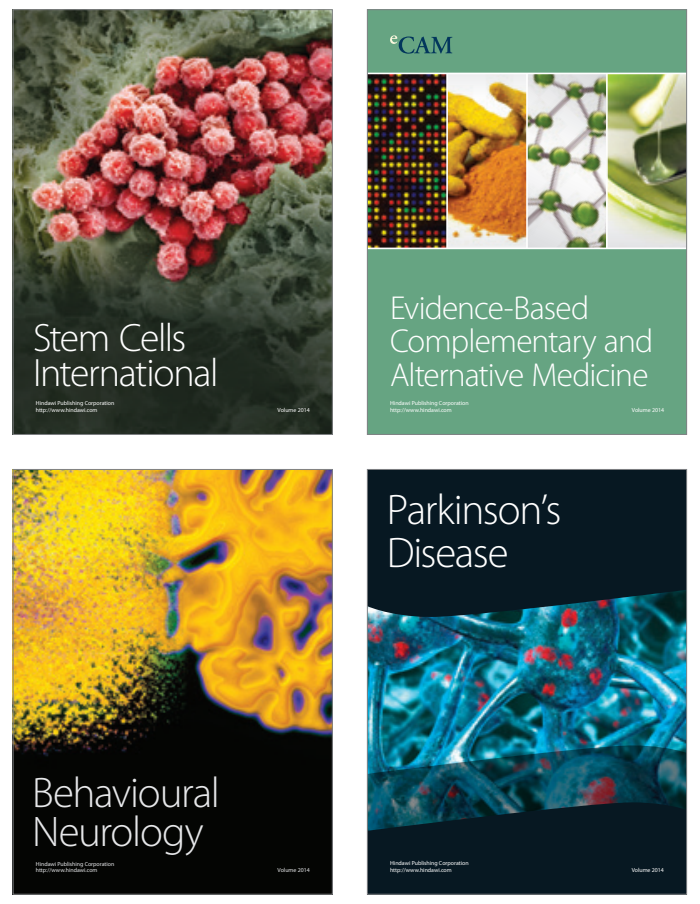
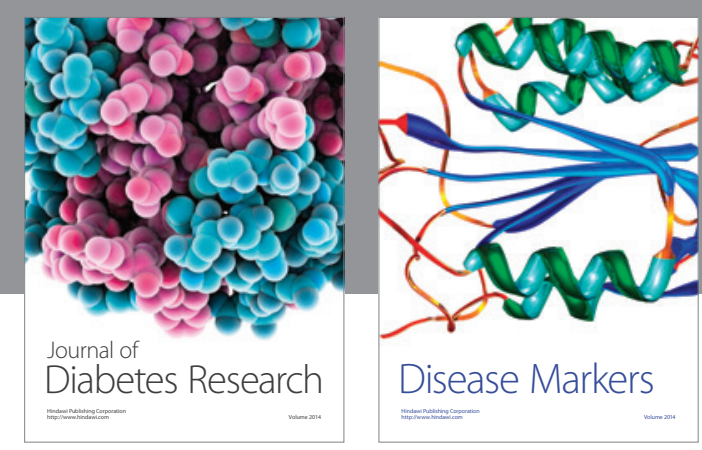

Disease Markers
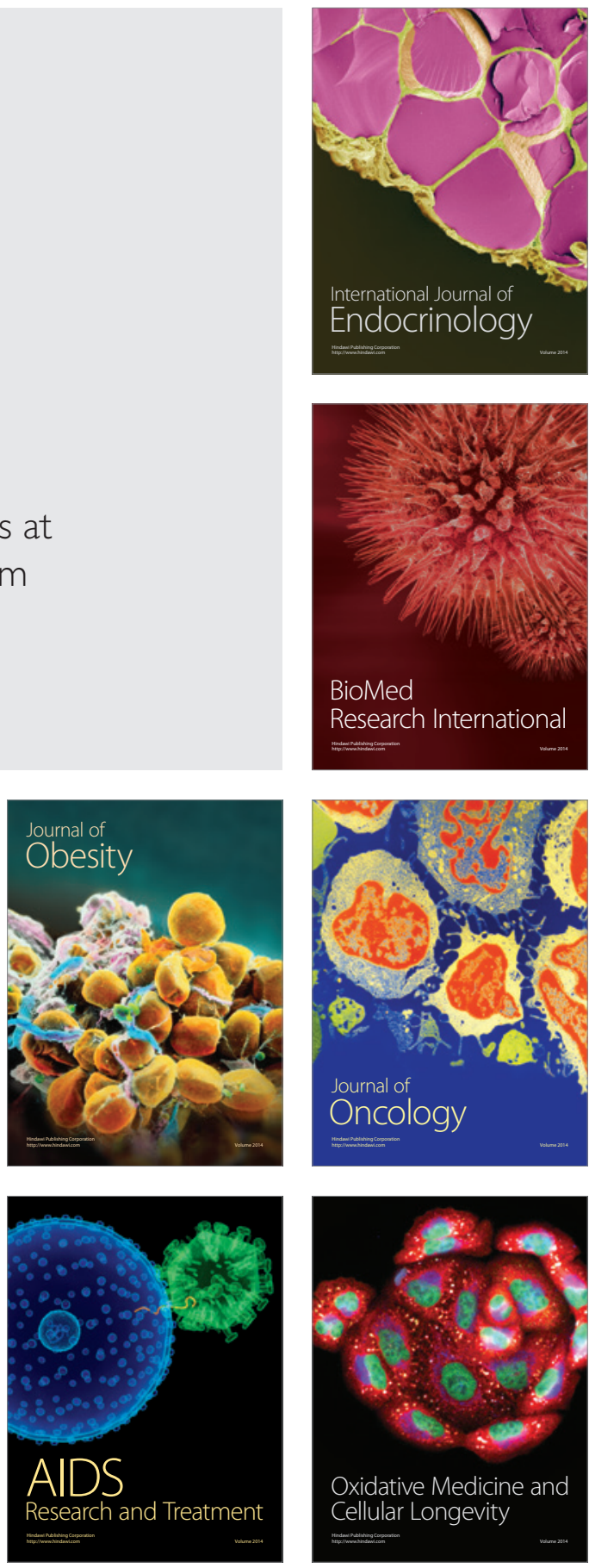